\title{
THE INFLUENCE OF ACTUATING AND CONTROLLING ON THE PERFORMANCE OF THE PROVINCIAL SPORTS WEEK COMMITTEE (PORPROV) XII SUMSEL THE BRANCH OF SOCCER SPORTS IN PRABUMULIHIN 2019
}

\author{
Fifin Sunarlie $^{1}$,Agustina Hanafi², Iyakrus ${ }^{3}$, Badia Perizade ${ }^{4}$ \\ ${ }^{1}$ Sriwijaya University,fifinsunarlie@gmail.com \\ ${ }^{2}$ Sriwijaya University,agustinahanafi29@gmail.com \\ ${ }^{3}$ Sriwijaya University,iyakrusanas@gmail.com \\ ${ }^{4}$ Sriwijaya University,badiaperizade1953@gmail.com
}

\begin{abstract}
This study aims to determine and analyze the effect of directing (actuating) and controlling (controlling) on the performance of the South Sumatra Province Porprov XII organizing committee in Prabumulih in 2019. The data used in this study are primary data by distributing questionnaires to 128 respondents. The analysis technique used is linear regression analysis. Based on the results of this study, using SPSS version 23 shows that: (1) Actuating has a positive and significant effect on the performance of the Porprov committee. (2) Controlling has a positive and significant effect on the performance of the Porprov committee. The percentage value of the coefficient of determination ( $R$ Square) of 0.524 illustrates that $52.4 \%$ of the variation in performance variables can be explained by the actuating and controlling variables at Porprov XII South Sumatra Football Branch in Prabumulih in 2019, while 47.6\% others are explained by causes other than the model under study.
\end{abstract}

Keywords : Actuating, Controlling, Performance, Porprov, Football

Abstrak
Penelitian ini bertujuan untuk mengetahui dan menganalisis pengaruh pengarahan (actuating) dan pengawasan (controlling) terhadap kinerja panitia penyelenggara Pekan Olahraga Provinsi (Porprov) XII Provinsi Sumatera Selatan di Kota Prabumulih Tahun 2019. Data yang digunakan dalam penelitian ini adalah data primer dengan menyebarkan kuesioner kepada 128 responden. Teknik analisis yang digunakan adalah analisis regresi linier. Berdasarkan hasil penelitian ini, dengan menggunakan SPSS versi 23 menunjukkan bahwa: (1) Pengarahan (actuating) berpengaruh positif dan signifikan terhadap kinerja panitia Porprov. (2) Pengawasan (controlling) berpengaruh positif dan signifikan terhadap kinerja panitia Porprov. Nilai persentase koefisien determinasi ( $R$ Square) sebesar 0,524 menggambarkan bahwa 52,4\% variabel kinerja dapat dijelaskan oleh variabel pengarahan (actuating) dan pengawasan (controlling) pada Porprov Sumsel XII Cabang Sepak bola Sumatera Selatan di Prabumulih tahun 2019, sedangkan 47,6\% lainnya adalah dijelaskan oleh penyebab selain model yang diteliti.

Kata Kunci: Pengarahan, Pengawasan, Kinerja, Porprov, Sepak Bola 


\section{A. INTRODUCTION}

Management is needed within an organization to regulate the course of an organizational process so that the goals of an organization can be achieved. Sports management is a combination of sports science and management science (Harsuki, 2003: 117-43). Sports management is a combination of skills and expertise related to planning, organizing, leadership, controlling, budgeting and evaluation in the context of an organization related to sports. Sports management is categorized into 3 groups according to Harsuki (2003: 119), namely: Institutional Management or Permanent Institutions, Event Management (sports parties) and Management of sports facilities. Football is the most popular sport and attracts worldwide interest today regardless of gender, age and social status. The most obvious sign of the statement that football is the most popular sport is the volume of information about football broadcast by the print and electronic media.

Sports achievements give birth to assets that can popularize and develop a region, city or country. Achievements are the results of efforts that have been achieved by groups of sportsmen (teams) or sportsmen in sports activities based on Law No.3 of 2005 on the National Sports System.

In connection with the Decree of the Governor of South Sumatra Number: 56 / KPTS / DISPORA / 2019 dated January 25, 2019 concerning the Appointment of Prabumulih City as the Venue for the South Sumatra Provincial Sports Week (PORPROV) XII-2019 and the Result of the Meeting of Members of the South Sumatra Province KONI on 12 September 2019 submitted the schedule for the implementation of the XII-2019 South Sumatra Provincial Sports Week (PORPROV) Sports Match in Prabumulih as attached.

It is understandable that several PORPROV XII-2019 sports will start the match before November 16, 2019, presumably so that all Prabumulih PORPROV XII-2019 Contingents can pay attention and prepare everything according to the schedule.

Porprov XII 2019 is a 2 (two) annual multi event Sports Party for South Sumatra Province which will be participated by 17 Regencies / Cities in South Sumatra in order to attract athletes who will be prepared for the National Championship, besides that as a gathering event, strengthen ties brotherhood and fostering unity and integrity and serve as a barometer of sports development in regencies / cities in South Sumatra. So that the implementation of the XII - 2019 Porprov South Sumatra can run successfully and successfully requires support from various parties, the South Sumatra Provincial Government fully supports the holding of the XII Sumsel Provincial Sports Week (Porprov) which was held from 16 to 26 November 2019 in the City Prabumulih.

The researcher chose soccer as the research target. Judging from the preparation for the Provincial Sports Week (Porprov) XII South Sumatra, in a short time, the organizing committee for the XII Provincial Sports Week (Porprov) South Sumatra, especially football sports, experienced obstacles in management activities in implementing functions including actuating and controlling functions. ) not fully implemented properly.

The final of the 2019 South Sumatra Porprov XII soccer match on Wednesday, November 20, 2019 between Mura and PALI entered an additional period of three minutes, the score at that time was 0: 1 for PALI's victory, there was chaos in the second minute of added time when a violation was committed by the soccer team PALI Regency ball so it must be done a free kick (direct free kick). When the PALI and Mura players were planning to grab a direct free kick ball, suddenly the Mura goalkeeper ran towards PALI's goal or the crowd of players who ended up fighting between the players and the officials on the Ria Jaya Prabumulih field. The cause of the commotion between the MusiRawas goalkeeper and the PALI player is not yet known. The match was resumed after being stopped for 10 minutes and PALI finally became the 2019 South Sumatra Porprov XII soccer champion in Prabumulih. 
Organizing successful or unsuccessful events must be used as a medium for learning and always thinking positively. The event organizing committee must be able to analyze, find solutions and record them to be used as the basis for the next Provincial Sports Week (Porprov). Based on this background, the researchers are interested in carrying out research with the title "The Effect of the Management Function of Actuating and Controlling on the Performance of the Provincial Sports Week Committee (Porprov) XII South Sumatra in the Football Sports Branch in Prabumulih 2019"

\section{B. LITERATURE REVIEW}

\section{Management Theory}

Management is a process / framework that involves the guidance / direction of a group of people toward real goals or organizational goals (Terry, 2005: 1). It consists of understanding how they should do it, determining how to do it, knowing what to do and measuring the effectiveness of the work already done. Management is defined as a profession according to Schein where a profession that is required to work professionally whose characteristics are professionals get their status because they achieve certain work performance standards, professionals make decisions based on general principles and those professionals must be determined by a code of ethics which strong (Schein, 2008: 2).

\section{Sports Management}

Sports management is the implementation of planning functions, organizing functions, directing functions and controlling functions in the context of an organization / institution which has the main objective of providing sports products, activities and services, namely physical fitness (Wawan, 2002: 2).

\section{Management function}

Management functions can be grouped into planning, organizing, implementing, and supervising (Terry, 2010: 9): Planning, Organizing, Actuating and Controlling. Actuating is an effort / encouragement to move group members so that they plan and strive to achieve the goals that have been scheduled earlier (Terry, 1993: 62). Controlling is the creation and implementation of methods and tools to ensure that the agenda is carried out in accordance with a predetermined agenda.

\section{Performance}

The performance of the word work performance or actual achievement achieved by someone (job performance or actual performance), namely the quality and quantity of work achieved by workers with the responsibilities that have been given in carrying out their duties (Mangkunegara, 2009: 67).

\section{Provincial Sports Week (Porprov)}

The 2019 Sumsel XII Provincial Sports Week (Porprov) is an effort to improve sports coaching achievements in spurring regional sports development in regencies / cities in South Sumatra to compete towards the best and foremost in upholding the banner of sports towards people who love and enjoy sports. (KONI, 2019). The 2019 Sumsel XII Provincial Sports Week (Porprov) held in Prabumulih City on November 16-26 2019 is the third South Sumatra Province Porprov held outside Palembang City which is expected to spur other districts / cities to build sports facilities so that each Regency / City can become a host. South Sumatra Province Porprov home thus the equitable distribution of sports development in South Sumatra can run well (KONI, 2019). 


\section{Sports Football}

Football is the most popular sport in Indonesia and even around the world. The sport of football is played by 2 teams of which 11 each have become a part of life in a country, including the archipelago, Indonesia. Often called the team because each team has 11 players. FIFA is a federation that deals with football issues located in Zurich, Switzerland.

In order to carry out the duties and roles of the trainer properly, the following must be carried out and monitored:

1) There is a coach and athlete interaction in building good communication.

2) The success of education will also be determined by how far we prioritize the interests, needs and abilities that must be improved from the foster / student subject (Dewey, 1964).

\section{RESEARCH METHOD \\ 1. Conceptual Framework}

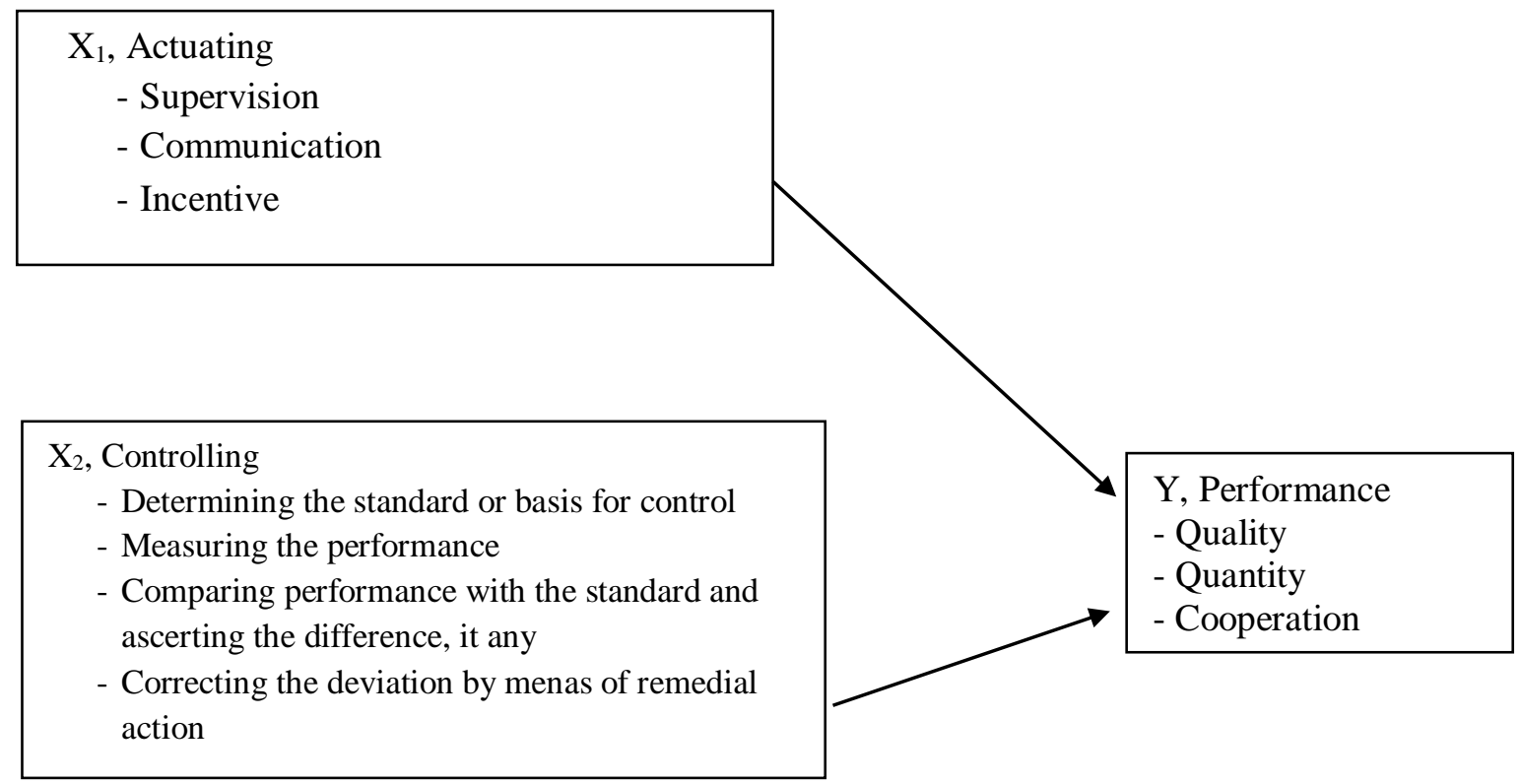

Figure 1. A path diagram that represents the causal relationship of $\mathrm{X}_{1}, \mathrm{X}_{2}$ to $\mathrm{Y}$ (Data processed by researchers, 2020)

\section{Hypothesis}

Hypothesis 1: Briefing (actuating) has a positive and significant effect on the performance of the South Sumatra Provincial Porprov organizing committee in 2019.

Hypothesis 2: Supervision (controlling) has a positive and significant effect on the performance of the South Sumatra Provincial Porprov XII organizing committee in 2019.

\section{Scope of Research}

In this study, actuating and controlling as the independent variable and the committee's performance as the dependent variable. The research object that the author uses is the South Sumatra Porprov XII committee for the soccer sport in Prabumulih in 2019. 


\section{Research Design}

A process in solving problems investigated by describing the situation of the subject and research object based on the facts found can be defined as descriptive research. In the research design entitled "The Influence of the Management Function of Actuating and Controlling on the Performance of the Provincial Sports Week Committee (Porprov) XII South Sumatra Football Sports in Prabumulih 2019" using descriptive research methods.

\section{Research Sample}

The sample is part / half or representative of the population to be corrected / researched (Arikunto, 2013: 174). Samples taken can provide reports / information to estimate the population is the purpose of sampling. The sampling technique used was saturated sampling method in this study. Saturated sampling is a technique in determining the sample when a member of the population is used as the sample. So the respondents in this study were 128 South Sumatra Provincial Porprov XII committees in Prabumulih 2019.

\section{RESEARCH RESULTS AND DISCUSSION}

\section{Multiple Regression Results}

Multiple linear regression analysis is a model to determine the effect of independent variables, namely actuating (X1) and controlling (X2) on the dependent variable, namely performance $(\mathrm{Y})$. Testing the hypothesis in this study using multiple regression analysis using the IBM SPSS version 23 program.

Table 1. Multiple Regression Analysis Test Results

Coefficients $^{\mathrm{a}}$

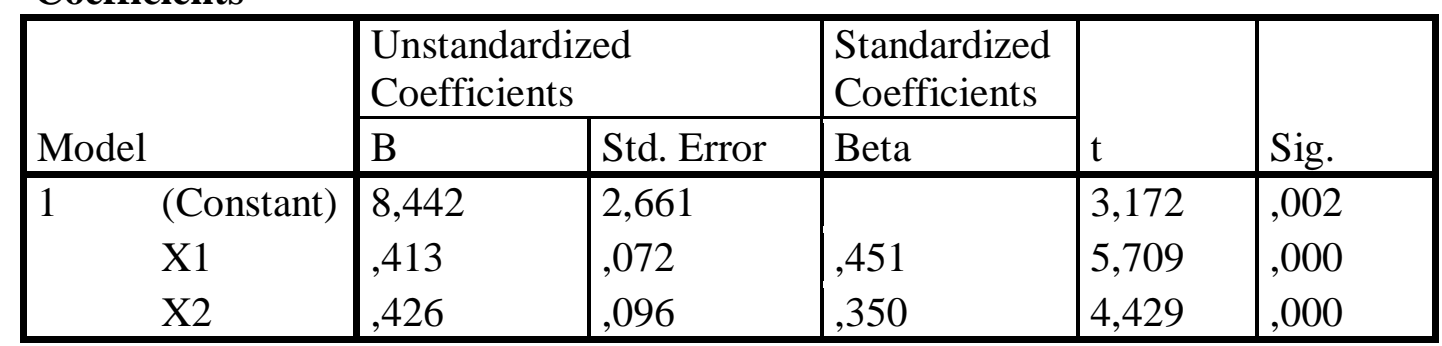

a. Dependent Variable: Y

Source: Questionnaire data processed using SPSS version 23

$$
\begin{aligned}
\mathrm{Y} & =\mathrm{a}+\mathrm{b}_{1} \mathrm{X}_{1}+\mathrm{b}_{2} \mathrm{X}_{2}+\mathrm{e} \\
& =8,442+0,451 \mathrm{X}_{1}+0,350 \mathrm{X}_{2}+\mathrm{e}
\end{aligned}
$$

\section{The result of the coefficient of determination}

The coefficient of determination is used to determine how much influence the interaction variable between actuating and controlling on performance. The results of the multiple regression test are as follows:

Table 2. Results of the coefficient of determination

Model Summary
\begin{tabular}{|l|l|l|l|l|}
\hline Model & $\mathrm{R}$ & R Square & $\begin{array}{l}\text { Adjusted R } \\
\text { Square }\end{array}$ & $\begin{array}{l}\text { Std. Error of } \\
\text { the Estimate }\end{array}$ \\
\hline 1 &, $724^{\mathrm{a}}$ &, 524 &, 517 & 3,954 \\
\hline
\end{tabular}

a. Predictors: (Constant), X2, X1

Source: Questionnaire data processed using SPSS version 23

The coefficient of determination (R2) of 0.524 illustrates that $52.4 \%$ of the variation in performance variables can be explained by the actuating and controlling variables at Porprov 
XII South Sumatra Football Branch in Prabumulih in 2019, while the other $47.6 \%$ are explained by other causes outside the model studied.

\section{F Test Results (Model Test)}

Table 3. F Test Results

ANOVA ${ }^{\text {a }}$
\begin{tabular}{|ll|l|l|l|l|l|}
\hline \multicolumn{2}{|l|}{ Model } & $\begin{array}{l}\text { Sum } \\
\text { Squares }\end{array}$ & of & Mean Square & F & Sig. \\
\hline 1 & Regression & 2153,827 & 2 & 1076,913 & 68,895 &, $000^{\mathrm{b}}$ \\
& Residual & 1953,916 & 125 & 15,631 & & \\
& Total & 4107,742 & 127 & & & \\
\hline
\end{tabular}

a. Dependent Variable: Y

b. Predictors: (Constant), X2, X1

Source: Questionnaire data processed using SPSS version 23

The prob value. $F$ count (sig.) In the table above the value is 0.00 less than the

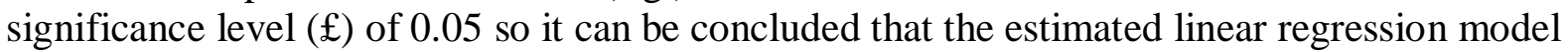
is suitable to be used to explain the effect of the variable actuating (X1) and controlling (X2) against performance (Y).

The conclusions in this study indicate that Ha in this study is accepted, which states that the estimated linear regression model is appropriate to use to explain the effect of the actuating and controlling variables on the performance of the South Sumatra Province Porprov XII committee in the Football branch of Prabumulih in 2019.

\section{T Test Results (Significance Test of Individual Parameters)}

Coefficients $^{\mathbf{a}}$

Table 4. Statistical Test Results t

\begin{tabular}{|l|l|l|l|l|l|}
\hline & \multicolumn{2}{|l|}{$\begin{array}{l}\text { Unstandardized } \\
\text { Coefficients }\end{array}$} & \multicolumn{2}{l|}{$\begin{array}{l}\text { Standardized } \\
\text { Coefficients }\end{array}$} & \\
\cline { 2 - 5 } Model & B & Std. Error & Beta & t & \multirow{2}{*}{ Sig. } \\
\hline 1 (Constant) & 8,442 & 2,661 & & 3,172 &, 002 \\
X1 &, 413 &, 072 &, 451 & 5,709 &, 000 \\
X2 &, 426 &, 096 &, 350 & 4,429 &, 000 \\
\hline
\end{tabular}

a. Dependent Variable: Y

Source: Questionnaire data processed using SPSS version 23

Based on the results of the partial test ( $t$ test) in the table, for the two independent variables actuating and controlling can be explained as follows:

1. Effect of Actuating (X1) on Performance (Y)

$\mathrm{H} 01: \beta 1=0$, There is no positive and significant partially / individually between the actuating variables on the committee's performance.

H01: $\beta 1 \neq 0$, There is a positive and significant partially / individually between the actuating variables on the committee's performance.

The results of the $t$ test for the actuating variable (X1) on performance (Y) show sig 0.000 , which means that the significance value is smaller than the probability 
value $0.05(0.000<0.05)$ and tcount shows the value of 5,709 , meaning that $t_{\text {count }}>$ $\mathrm{t}_{\text {table }}(5,709>1,97867)$.

Then the conclusion is that $\mathrm{H}_{01}$ and $\mathrm{H}_{\mathrm{a} 1}$ are accepted. So it can be said that actuating has a significant effect on the performance of the committee. Because the tcount is positive, the actuating variable increases, the committee's performance will also increase significantly. On the other hand, if the actuating variable decreases, the committee's performance will also decrease significantly.

2. The Effect of Controlling (X2) on Performance (Y)

$\mathrm{H} 01: \beta 1=0$, There is no positive and significant partially / individually between the controlling variables on the committee's performance.

$\mathrm{H} 01: \beta 1 \neq 0$, There is a positive and significant effect partially / individually between the controlling variable on the committee's performance.

The $t$ test results for the controlling variable (X2) on performance (Y) show sig 0,000 , which means that the significance value is smaller than the probability value $0.05(0,000<0.05)$ and tcount shows the value of 4,429 , meaning that $t_{\text {count }}>t_{\text {table }}$ $(4,429>1,97867)$.

Then the conclusion is that $\mathrm{H}_{01}$ and $\mathrm{H}_{\mathrm{a} 1}$ are accepted. So it can be said that controlling has a significant effect on the performance of the committee. Because tcount is positive, the controlling variable increases, the committee's performance will also increase significantly. On the other hand, if the controlling variable decreases, the committee's performance will also decrease significantly.

\section{The Most Dominant Variable Affecting Committee Performance}

Based on the values in Table 4., It can be seen that the most dominant variable affecting the performance of the committee is actuating because it has a beta value of 0.451 which is greater than the beta value of the controlling variable of 0.350 . This means that the indicator of the variable actuating has a greater influence on the performance of the South Sumatra Province Porprov XII committee for the Football Branch in Prabumulih in 2019.

\section{Discussion}

\subsection{Effect of Actuating on Performance}

From the analysis, it was found that actuating had a positive and significant effect on performance. The results of the analysis are in accordance with the hypothesis which states that actuating $\left(\mathrm{X}_{1}\right)$ has a positive effect on performance $(\mathrm{Y})$. So it can be concluded that the better actuating in supervision, communication and incentives tends to be able to improve the performance of the South Sumatra Porprov XII committee for soccer in Prabumulih in 2019.

Based on the results of the frequency distribution analysis, it can be said that the respondents have very good perceptions of actuating variables. This can be seen in accordance with the results in Table 4.4.1. that the percentage of respondents who agree with statements related to actuating overall exceeds the value of $50 \%$. And the percentage of respondents who strongly agree with statements related to actuating overall exceeds the value of $28 \%$.

Researchers in conducting research examined the dimensions of Actuating, namely Supervision, Communication and Incentive. With the better interaction that can be presented, it can increase the sense of brotherhood and strengthen the friendship between the committee. According to researchers, with the presence of better actuating, it can improve the 
performance of the committee in the South Sumatra Porprov XII sports in Prabumulih in 2019.

\subsection{Effect of Controlling on Performance}

From the analysis, it was found that controlling had a positive and significant effect on performance. The results of the analysis are in accordance with the hypothesis which states that controlling $\left(\mathrm{X}_{2}\right)$ has a positive effect on performance $(\mathrm{Y})$. So it can be concluded that it is as good as controlling in Porprov activities with dimensions consisting of Determining the standard or basis for control, Measuring the performance, Compare implementation with standards and find if any difference (Comparing performance with the standard and ascerting the difference, it any), Correcting the deviation by means of remedial action, so it tends to increase the performance of the South Sumatra Porprov XII committee for soccer in Prabumulih in 2019.

Based on the results of the frequency distribution analysis, it can be concluded that the respondents have very good perceptions of the controlling variable. This can be seen in accordance with the results in Table 4.4.2. that the percentage of respondents who agree with statements related to controlling as a whole exceeds the value of 50\%. As well as the percentage of respondents who strongly agree with statements related to controlling as a whole exceeds the value of $33 \%$.

\subsection{Most Dominant Variable on Performance}

From the results of the Beta value analysis, it was found that actutating had a more dominant influence than controlling on the committee's performance. So that these results are in accordance with the hypothesis which states that actuating $\left(\mathrm{X}_{1}\right)$ has a more dominant influence on the performance (Y) of the South Sumatra Porprov XII committee for soccer in Prabumulih in 2019.

\section{E. CONCLUSIONS AND SUGGESTIONS}

1. Conclusion

a. The Actuating variable has a positive and significant effect on the performance of the South Sumatra Province Porprov XII committee for the Football Branch in Prabumulih in 2019.

b. The Controlling variable has a positive and significant effect on the performance of the South Sumatra Province Porprov XII Football Branch in Prabumulih in 2019.

\section{Suggestions}

a. Actuating has a positive and significant effect on the performance of the South Sumatra Porpov XII committee for soccer in Prabumulih in 2019. Therefore it is necessary to always improve the dimensions of actuating obtained by the committee in porprov activities.

b. Controlling has a positive and significant effect on the performance of the South Sumatra Porpov XII committee for soccer in Prabumulih in 2019. So in repeated implementation (every 2 years), this Porprov activity needs to always improve the dimensions of controlling that are felt by the committee.

c. This research is expected that the organizers of Porprov can provide encouragement and motivation so that their athletes can excel and improve their good performance so that they can be an example for other activities. 


\section{REFERENCE}

\section{Books}

Acker, William R.B. (1965). Japanese Archery. Rutland, Vermont \&Tokyo: Charles E. Tuttle Co.

Anwar PrabuMangkunegara. (2009). Performance Evaluation of Human Resources. Bandung: Publisher RefikaAditama.

AptaMylsidayu and FebiKurniawan. (2015). Basic Coaching Science. Bandung: CV Alfabeta.

Arikunto, S. (2013). Research Procedure: A Practical Approach. Jakarta: RinekaCipta.

Betty Eric C. (2007). New Methods of Soccer Defense Training. Bandung: Pionir Jaya.

Bucher Charles A., and Krotee, Marc L. (2002). Management of Physical Education and Sport, Boston: McGraw-Hill.

Dewey, John. (1964). Democracy and Education. New York: The Macmillan Company Djarmarah and Zain. (2006). Teaching and Learning Strategies. Rieneka Cipta : Jakarta.

Ekawati, S. Wahyuni and Puji, Mulyono. (2006). Module for Social Research Methods. Department of Communication and Community Development. Faculty of Human Ecology: Bogor Agricultural Institute.

Harsuki. (2003). Recent Sports Developments: Experts Study. Jakarta: PT Raja GrafindoPersada.

Hasibuan, Malayu S.P. (2009). Management: Basic, Definition, and Revised Edition Issue Problems. Jakarta: Earth Literacy.

Muhajir. (2007). Sports and Health Education. Yudistira : Bandung

PabunduTika. (2010). Organizational Culture and Company Performance Improvement, mold 3. Jakarta: PT. Earth Literacy.

Parkhouse Bonnie L. (2001). Sport Administration. United states: Study and Teaching.

R.Terry, George and Leslie W.Rue. (2010). Management Basics. Jakarta: Earth Literacy.

Ratminto, dkk (2012). Service Management. Yogyakarta : Student Library.

Schein, E. H. (2008). Organizational Culture and Leadership. San Francisco: Jossey-Bass

Simanjuntak. (2005). Management And Performance Evaluation. Jakarta: Faculty of Economics, University of Indonesia.

Terry, George. (2005).Management Basics. Jakarta: PT. BumiAksara.

Wawan S. Suherman. (2004). Competency-Based Curriculum of Physical Education Development Theory and Practice. Yogyakarta : FIK UNY.

Wijayanti, Irine Diana Sari. (2008). Management Editor: Ari Setiawan. Yogyakarta: Cendikia Partners.

\section{Journals}

Arne Pettersen. (2015). The Effect of Speed Training on Spirit and Agility Performance In Famale Youth Soccer Players. Lase Journal Of Sport Science, 2015/6/2.

Awaluddin, Hendra. (2018). Management Functions in Procurement of Community Agricultural Infrastructure in Watatu Village, Banawa Selatan Distric, Donggala Distric. Journal Untad, Vol 2 No. 1, April 2018, 1-12.

Felipe Manuel Clement and Fernando Lourendo. (2015). The Social Network Analysis of Switzerland Footbal Team on FIFA World Cup 2014 "Journal Unnes Of Physical Education and Sport (JPES), 15 (1): 136-141.

Gema, A. R., \& Soenyoto, T. (2016). Soccer Competition Management Sumsel Super League (SSL) Palembang City. Journal Unnes of Physical Education and Sport, 5 (1), 8-16. 
Handoko, T. Hani, 2008. Personnel and Human Resources Management Second Edition, Yogyakarta : BPFE.

Haikal, A. (2017). The Management Function of Human Resources is to Improve the Effectiveness of the Performance of Human Resources on BSITV. National Conference of Social Sciences \& Technology (KNiST)Maret 2017, pp. 683-691.

Haryadi W.M., dkk(2016). Study of the management of football sports coaching in the Bogor City Football Association Club by the Bogor City Youth and Sports Office, Journal Unida Governansi, Vol. 2 No. 1, April 2016.

Michailidis, Yianis. (2013). "Small Sided Games in Soccer Training". Journal Unnes of Physical Education and Sport, 13 (3): 392-399.

Natal, Y. R. (2018). Long Distance Running Athletic Sports Development Management 10. 000 meters at the Indonesian Athletic Association (PASI) East Nusa Tenggara Province 2017. Citra Bakti Scientific Journal, Vol 5, No. 1, Maret 2018.

Nugroho, S. (2016). The Management of Indonesian Renewal Unity of Cilacap District. Judika (Unsika Education Journal), Vol.4, No. 2, November 2016.

Rawe. (2018). Management Analysis of Youth and Sports Education Office in Improving Sports Achievement in Ende Regency. SportiveJournal of Physical Education, Sport and Recreation, Vol 1, No. 2, Maret 2018.

Rusli. (2015). Analysis of Student Sport Development, Pidie Jaya Jaya Jaya District. Journal Unsyiah of Sport Pedagogy, Vol. 5, No. 1, April 2015.

Saffron. (2012). Management and Public Service Reform in the Context of the Indonesian Bureaucracy (Theory, Policy, and Implementation). Yogyakarta: Aditya Media Publishing.

Sofie, F., Fitria, S.,E. (2013). Identification of Human Resource Management Functions in Medium Enterprises (Study at CV. Kota Agung). Journal Wacana Ekonomic, Vol 18; No. 01, 2018 (001-012).

Sulistiyono. (2012). Transformation of Football Club Management in Indonesia. Journal Unnes of Indonesian Sport Science Media, Vol 2, Issue 2, December 2012.

Sulistyono, Pandhu. (2018). Analysis of Management Functions of AjiSantoso International Football Academy (ASIFA) Malang, East Java. Journal UNY of Health and Recreation Physical Education, Vol. VII, No.3.

Wahyuningtyas. (2018). The Condition of Anniversary of the Committee before the 2018 Nasmori Color Run Event. Journal Unesa of Sports Health, Vol. 07, No.02, July 2019 Issue p. 57-64.

Yunida, E., dkk. (2017). Independent Development ManagementBasketball Club(MBBC)Pontianak, West KalimantanThe year 2016. Journal Unnes of Physical Education and Sports, JPPES 6 (2) (2017) : 125-132

\section{Website}

Deo, Alexandro. (2013). Interest in Learning. Accessed on February 24, 2020 (http://alexandro-tips.blogspot.co.id/2013/07/pengentuk-minat-belajar-menurut-b Several-ahli.html) 